\title{
Brown bear damage: patterns and hotspots in Croatia
}

\author{
Dário Hipólito, Slaven Relić, Luís Miguel Rosalino, Seth M. Wilson \\ CARLOS FONSECA and ĐURO HubER
}

\begin{abstract}
Human-bear conflicts resulting from livestock depredation and crop use are a common threat to the brown bear Ursus arctos throughout its range. Understanding these conflicts requires the recording and categorization of incidents, assessment of their geographical distribution and frequency, and documentation of the financial costs and the presence of any preventative measures. Damage compensation schemes can help mitigate conflicts and, in some cases, improve acceptance of bears. This study aims to elucidate the major factors determining the patterns of damage caused by bears, examine the effectiveness of preventative measures in reducing such damage, and identify bear damage hotspots in Croatia. Our analysis is based on damage reports provided by hunting organizations to the Croatian Ministry of Agriculture during 2004-2014. The highest number of claims were made for damage to field crops and orchards. Damage to livestock, agricultural crops and beehives resulted in the highest total cost to farmers. Damage to beehives and to automatic corn feeders for game species incurred the highest cost per damage event. We identified a hotspot for bear damage claims in Croatia, located near Risnjak National Park and the border with Slovenia. Damage appears higher in areas that have more villages closer to protected areas and a greater per cent of forest cover, indicating a synergistic effect of protected environments that facilitate bear movements and the presence of human activities that provide easily accessible food for bears.
\end{abstract}

Keywords Brown bear, Croatia, damage compensation, Dinaric Mountains, human-wildlife conflict, large carnivores, Ursus arctos, wildlife management

Supplementary material for this article is available at https://doi.org/10.1017/Soo30605318000236

DÁrio Hipólito* (Corresponding author), SLAVen Relić and Đuro Huber Biology Department, Faculty of Veterinary Medicine, University of Zagreb, Heinzelova, Zagreb, Croatia. E-mail dhipolito@ua.pt

Luis Miguel Rosalino and Carlos Fonseca Departamento de Biologia \& CESAM, Universidade de Aveiro, Aveiro, Portugal

Seth M. WiLson Northern Rockies Conservation Cooperative, Jackson, USA

*Also at: Departamento de Biologia \& CESAM, Universidade de Aveiro, Aveiro, Portugal

Received 21 July 2017. Revision requested 21 September 2017.

Accepted 25 January 2018. First published online 25 September 2018.

\section{Introduction}

Tegative interactions between people and wildlife, often 1 referred to as human-wildlife conflict, are one of the primary challenges to large carnivore conservation (Treves \& Karanth, 2003), particularly in Europe where human populations and activities often overlap with the ranges of large carnivores. Such negative interactions are often related to wild animals' use of biological resources that are produced (e.g. crops, livestock, beehives) or exploited (e.g. game) by humans (Kruuk, 2002). The evaluation of such damage, the underlying drivers and the efficacy of damage prevention and compensation frameworks is crucial for large carnivore conservation (Schwerdtner \& Gruber, 2007; Rigg et al., 2011). This is particularly important for species such as the brown bear Ursus arctos because damage caused by bears tends to attract less public attention than that caused by wolves or large felids. As a result, public institutions focus less on assessing the impact of such damage on rural populations, which limits the efficiency of mitigation measures (Can et al., 2014). In this analysis we use the term conflict to refer broadly to incidents caused by brown bears and the term damage to refer specifically to economic losses.

Brown bears were present historically throughout continental Europe (Zedrosser et al., 2000; Trouwborst, 2010), but were nearly extirpated from western and southern Europe and from many areas in eastern and northern Europe before World War II, primarily as a result of deforestation and human persecution (Zedrosser et al., 2000; Huber et al., 2008a; Trouwborst, 2010). However, bear behaviour is plastic and bears can adapt to certain levels of disturbance. This, along with increasing conservation efforts, rural abandonment and rewilding of many European regions, has allowed bears to gradually reoccupy former habitats (Huber et al., 2008a).

In Croatia brown bears occur in the Dinaric Mountains, from Slovenia to Bosnia and Herzegovina and further south-east (Servheen et al., 1999; Zedrosser et al., 2000), with an estimated population of c. 1,00o (Kocijan \& Huber, 2008; Majić et al., 2011; Knott et al., 2014). Brown bear management is challenging because of the species' biological and ecological characteristics (large body, long gestation period and opportunistic feeding strategy) and its history of conflicts with people. In Croatia the majority of human-bear conflicts result from livestock depredation and crop use (Nyhus et al., 2005; Majić et al., 2011; Bautista et al., 2017). The most common strategies to 
minimize these conflicts include prevention tools and compensation schemes (Treves \& Karanth, 2003). In Croatia the latter have been the focal approach, aiming to distribute damage costs between the conservation beneficiary (government or hunting organizations) and the person or institution suffering the damage (Fourli, 1999; Nyhus et al., 2003). There are two types of compensation schemes: expost compensation, which is paid after damage occurs, and compensation in advance, which is paid prior to any damage occurring and based on an estimation of expected losses (Schwerdtner \& Gruber, 2007). Regardless of the type of scheme being used, the priority should be to prevent damage from occurring or to minimize its impact. This requires an understanding of the types and cost of damage events, their frequency, and the spatial distribution and patterns of such incidents. (Gunther et al., 2004; Wilson et al., 2006; Can et al., 2014).

In Croatia mitigation of human-bear conflict is based primarily on the ex-post compensatory approach, although bear hunting is also allowed as a strategy to minimize conflicts. Ex-post compensation is managed and paid by local hunting organizations, which have an allocated quota for bear hunting (Huber et al., 2008a; Majić et al., 2011; Bišćan et al., 2016). However, when damage occurs in national parks, the government is responsible for paying compensation (Huber et al., 2008a). Damage will usually be fully compensated only if the person or institution suffering it has previously implemented protection measures (e.g. proper fencing) and behaves responsibly (e.g. by guarding livestock and not planting crops that entice bears near the forest edge; Huber et al., 2008a,b); but occasionally hunting organizations compensate for damage in the absence of protection measures by providing the farmer with an amount of crops equivalent to the damage caused by bears. To apply compensation strategies efficiently, it is crucial to review available data, so that damage patterns can be detected and research needs identified (Bruggers et al., 2002). No such analysis has previously been carried out in Croatia, and we aim to contribute new insights for a better understanding of human-bear conflicts. Specifically, our objectives are to (1) analyse brown bear damage in Croatia during 2004-2014, including the type of damage, associated costs, and the factors determining damage patterns, (2) determine if preventative tools reduce brown bear damage and associated costs, and (3) identify bear damage hotspots.

\section{Methods}

\section{Damage claims and costs}

We analysed all damage reports for 2004-2014 that were systematically collected and provided annually by hunting organizations to the Croatian Ministry of Agriculture. When damage occurs and is reported, the hunting organization responsible for managing the area fills out a report and sends it to the Croatian Ministry of Agriculture, where the information about the type and amount of damage, date and location of the incident, name of the injured party, and presence of any preventative measures are compiled. We included in our analysis all reported claims that were confirmed as damage caused by bears, including claims that were and were not subsequently compensated for.

We analysed the number of damage claims, the cost associated with the damage and the frequency of incidents by damage type. Damage type was categorized as losses associated with crops, orchards/vineyards (including domestic gardens), beehives, and wildlife/game feeders. Corn feeders are widely used in Croatia to provide extra food for game species such as red deer Cervus elaphus, wild boar Sus scrofa and bears. Additionally, we analysed incidents involving damage to property such as barn doors, vehicles, shooting posts or silage depots, and losses of livestock and domestic animals. For the latter category, we assessed the number of bear attacks per type of livestock and domestic animal (poultry, cattle, red deer, dogs, donkeys, goats, horses, ostriches, pigs, rabbits and sheep). To test whether there was a positive or negative trend in the total number of damage events per year we used a linear regression model (Zar, 2010), and $\chi^{2}$ tests (Zar, 2010) to assess if the number of damage events (observed values) differed between damage types. We gathered data on the intensity of livestock depredation by bears across Europe using the estimations of the annual per capita loss presented by Kazcensky (1999), i.e. the number of livestock lost per year and per bear. For Croatia, we used the methodology described by Kazcensky (1999) to estimate this metric, allowing us to compare livestock depredation across all European countries where brown bears occur. The number of bears used for this calculation was the annual estimate of the total bear population in Croatia, as provided by the hunting organizations. To identify damage types that have the biggest impact in terms of cost, we defined the following damage categories: Wildlife feeder, Beehive, Orchards, Crops, Livestock and domestic animals, and Other. We used partial least square regressions (Roy \& Roy, 2008; Carrascal et al., 2009) to determine the influence of these damage categories (all binary variables), together with the presence of protective measures on the damage compensation paid. Model significance was assessed by a Stone-Geisser Q2 test, which evaluates the accuracy of models and their parameters compared to observed values through a cross-validation process (Götz et al., 2010). We used Q2 $\geq 0.0975$ (Cao et al., 2008) to assign significance to the contribution of the predictors, and $R^{2}$ to assess the proportion of the total variance that was explained by the model (Zar, 2010).

We evaluated whether the frequency of damage to domestic animals decreased when protective measures were used, by testing whether the number of damage claims differed between properties using protection measures (Cat1) 
and those without them (Cat2), using a $\chi^{2}$ test. All analyses were performed using $R$ 3.2.3 (R Development Core Team, 2015), and partial least square regression models were built using the package plsdepot (Sanchez, 2012).

\section{Damage hotspots}

We analysed the spatial distribution of damage claims using a geographical information system. Hotspot areas were delineated using the Optimized Hot Spot Analysis tool in ArcMap 10.4.1 (Esri, Redlands, USA). Each damage location, defined by its latitude and longitude coordinates, was assigned to a $10 \times 10 \mathrm{~km}^{2}$ grid cell on a map of Croatia. For each grid cell, we tallied the number of damage events and calculated the Getis-Ord Gi* statistic (Songchitruksa \& Zeng, 2010) by scoring it with a $z$-score and probability. The resulting $z$-score was based on the distance between cells and the number of damage events within them. Thus, cells with high numbers of damage events that were in close proximity to each other produced high $z$-scores. To be characterized as a statistically significant hotspot, a cell had to be surrounded by cells with high $z$-scores and probabilities (Ord \& Getis, 1995). These statistics allowed us to compare the number of damage events in each cell and its neighbouring cells to the mean number of damage events per grid cell across the entire study area. Where any observed difference is larger than expected by chance, a statistically significant $z$-score is achieved. We used the Getis-Ord $\mathrm{Gi}^{*}$ statistic to identify patterns in positive spatial clustering. This allowed us to discriminate between cells of high and low spatial association (Songchitruksa \& Zeng, 2010), and to generate a density surface raster layer.

\section{Factors influencing bear damage frequency}

To evaluate which factors influence damage frequency (the number of damage claims per area) in each hunting reserve (the damage compensation management unit in Croatia), we used generalized linear models (Zuur et al., 2007), with a Gaussian distribution. We defined four hypotheses that could potentially explain differences in damage frequency between different areas.

The land cover hypothesis $\left(\mathrm{H}_{1}\right)$ assumes that herbaceous vegetation is a habitat used by bears (Posillico et al., 2004) and examines whether damage occurred more frequently in such areas. Land cover variables were extracted from Corine 2012 land cover maps (CLC, 2012): per cent of forests, scrub and/or herbaceous vegetation, artificial surfaces or houses, arable land and permanent crops, heterogeneous agricultural areas (a surrogate for the presence of human activities) and wetlands, water bodies, and the number of villages within each hunting reserve (see CLC, 2012, for definitions of these categories).
The landscape protection status hypothesis $\left(\mathrm{H}_{2}\right)$ tests whether areas where bears were not hunted acted as source environments (Hansen, 2011) and were therefore subject to more frequent damage events. The landscape protection status is the distance in $\mathrm{km}$ between the edge of a hunting reserve and the nearest edge of a protected area.

The bear population characteristic hypothesis $\left(\mathrm{H}_{3}\right)$ examines whether more stable populations and constant presence of bears lead to more frequent damage events. Bear occurrence was based on the Croatian Bear Management Plan and the LIFE DinAlp Bear project report (i.e. constant vs sporadic presence; Huber et al., 2008b; Skrbinšek et al., 2015) and the number of bears $\geq 8$ years old that were hunted and killed in hunting reserves was used as a surrogate for population stability.

The hybrid hypothesis $\left(\mathrm{H}_{4}\right)$ used variables included in the best-fit models from each of the previous hypotheses where the $95 \%$ confidence interval of their coefficients did not include zero. This allowed us to detect a positive or negative influence on the damage frequency.

We first tested for data multicollinearity using Spearman's correlation coefficient ( $\rho$; Zar, 2010), and identified outliers by using a $\chi^{2}$ test (Komsta, 2011). Variables were considered highly correlated if $\rho>0.7$. When two covariates were correlated we excluded those less correlated with the dependent variable.

We built models using all possible combinations of the covariates for each hypothesis and based our model selection on the Akaike Information Criterion corrected for small samples (AICc; Burnham \& Anderson, 2002). Models with $\triangle \mathrm{AICc}<2$ were considered the most parsimonious (Burnham \& Anderson, 2002).

We compared the AICc of the best models in each hypothesis and that of the hybrid hypothesis $\left(\mathrm{H}_{4}\right)$ using $R(\mathrm{R}$ Development Core Team, 2015) together with the MuMIn package (Barton, 2015). Model evaluation was performed using the pseudo $\mathrm{R}^{2}$ and the likelihood ratio test comparing the deviance of the null best model (Dobson, 2002).

\section{Results}

\section{Damage claims and costs}

During 2004-2014 a total of 343 claims for damage caused by bears were reported to the Croatian Ministry of Agriculture, a mean of c. 31 per year. A total of EUR 71,477 was paid in compensation during this period, with a mean of EUR 6,498 per year. There was no trend in the annual number of claims over this period (Spearman correlation coefficient $=-0.451, \mathrm{P}=0.164)$. There was a significantly higher proportion of claims associated with crop damage to corn, oat and hay fields compared to the other types of damage ( $31 \%$ of all damage claims; $\chi^{2}=32.318 ; \mathrm{P}<0.05$; Fig. 1 ). 


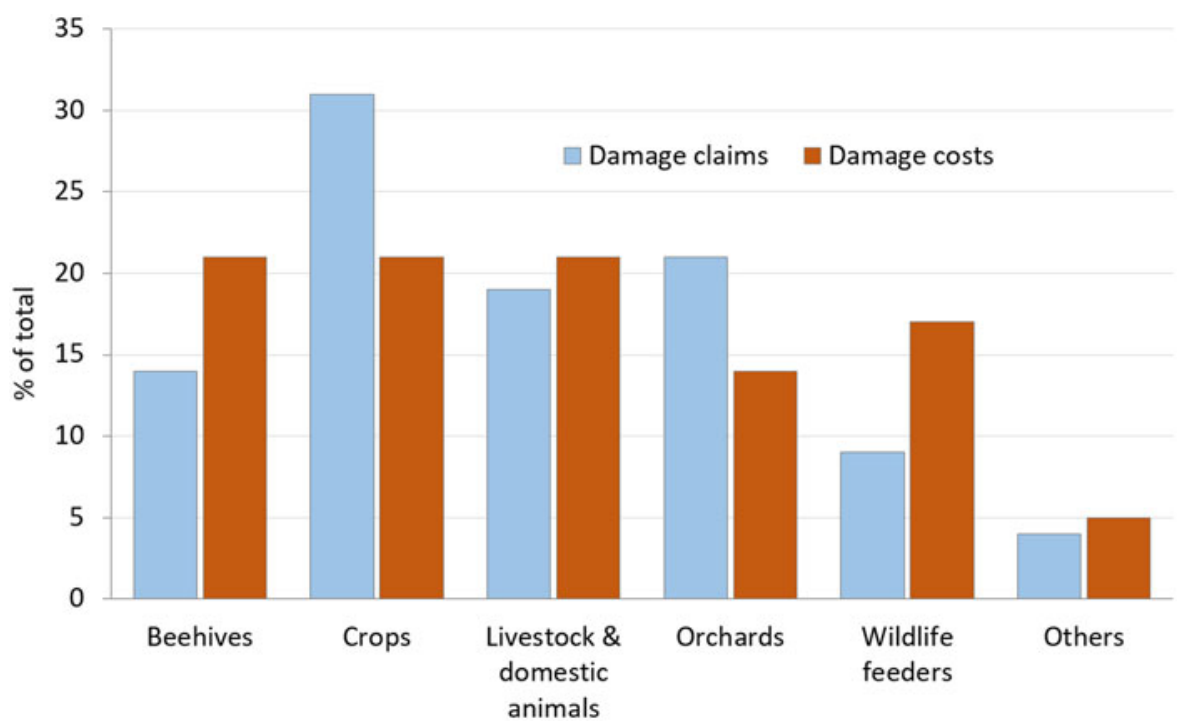

FIg. 1 Proportion (\%) of different types of asset damaged by brown bears Ursus arctos of the total number of bear-related damage claims and associated costs in Croatia (2004-2014).
A different pattern was evident when we analysed the amount of damage costs. The majority of the total compensation was paid for damage to beehives, crops and domestic animals, including livestock (21\% each; Fig. 1). The number of damage claims and associated costs from beehives, crops and domestic animals was significantly higher $\left(\chi^{2}=23.838\right.$; $\mathrm{P}<0.05)$ where protective measures were absent. Most livestock damage claims were associated with sheep $(34 \%, 92$ sheep killed in 22 attacks, mean 4.2 per attack) and chickens (28\%; 169 chickens killed in 18 attacks, mean 9.4 per attack), with multiple individuals usually killed in an incident. Attacks on individual animals involved mostly large mammals such as donkeys, horses and red deer (which are also raised as farm animals in Croatia), but also ostriches and dogs (Supplementary Table 1). The number of animals killed per attack was typically greater where protective measures had been implemented compared to those where protective measures had not been implemented (Supplementary Table 1).

The reports showed that 240 beehives, 170 of which were unprotected, were damaged in 47 events. The mean number of beehives damaged per attack was 5.1 (5.4 without and 4.4 with protection) and the mean monetary value per damaged beehive was EUR 100.

The mean intensity of livestock depredation (annual per capita loss) during 2004-2014 was 0.05 livestock per bear per year. For beehives, the intensity of depredation was 0.03 hives per bear per year. These calculations are based on the estimated annual bear population in the country, which ranged from 850 in 2004 to 1,000 in 2014.

Partial least squares regression analysis showed that c. $19 \%$ of damage cost variability was explained by the type of damage and whether protective measurements were present. The Stone-Geisser Q2 test value was 0.159 , indicating that model estimates were accurate (i.e. $>0.0975$ ). The amount of compensation was most influenced by the type of damage, with higher values primarily associated
TABLE 1 Influence of assessed variables on compensation paid for damage caused by brown bears Ursus arctos in Croatia during 2004-2014, with their loads and weights on the first component of partial least squares regression. A variable's weight is its contribution to the first component of partial least squares regression.

\begin{tabular}{lrr}
\hline Variable & Load & Weight \\
\hline Wildlife feeders & 0.448 & 0.482 \\
Beehives & 0.408 & 0.406 \\
Crops & 0.113 & 0.073 \\
Livestock \& domestic animals & 0.108 & 0.103 \\
Orchards & -0.780 & -0.750 \\
Other & 0.082 & 0.058 \\
Protection measures & -0.064 & -0.141 \\
\hline
\end{tabular}

with beehives $($ load $=0.408$, weight $=0.406$; Table 1$)$ and wildlife feeders (load $=0.448$, weight $=0.482$; Table 1 ). Conversely, orchard damage contributed less to damage costs, with a negative correlation with the total cost of damage $($ load $=-0.780$, weight $=-0.750$; Table 1$)$.

\section{Damage hotspots}

We identified a hotspot where most damage claims were clustered, in the north-west of the brown bear range in Croatia, near the border with Slovenia (Fig. 2).

\section{Factors influencing bear damage frequency}

The values for per cent cover of forests and scrub and/or herbaceous vegetation were highly correlated $(r=-0.701$, $\mathrm{P}<0.001)$ and therefore we excluded the latter from the generalized linear model analysis, as it was less correlated than the former with the dependent variable. We identified three outliers, which were also excluded. Five, one and three models were identified as the best models for the land cover, 


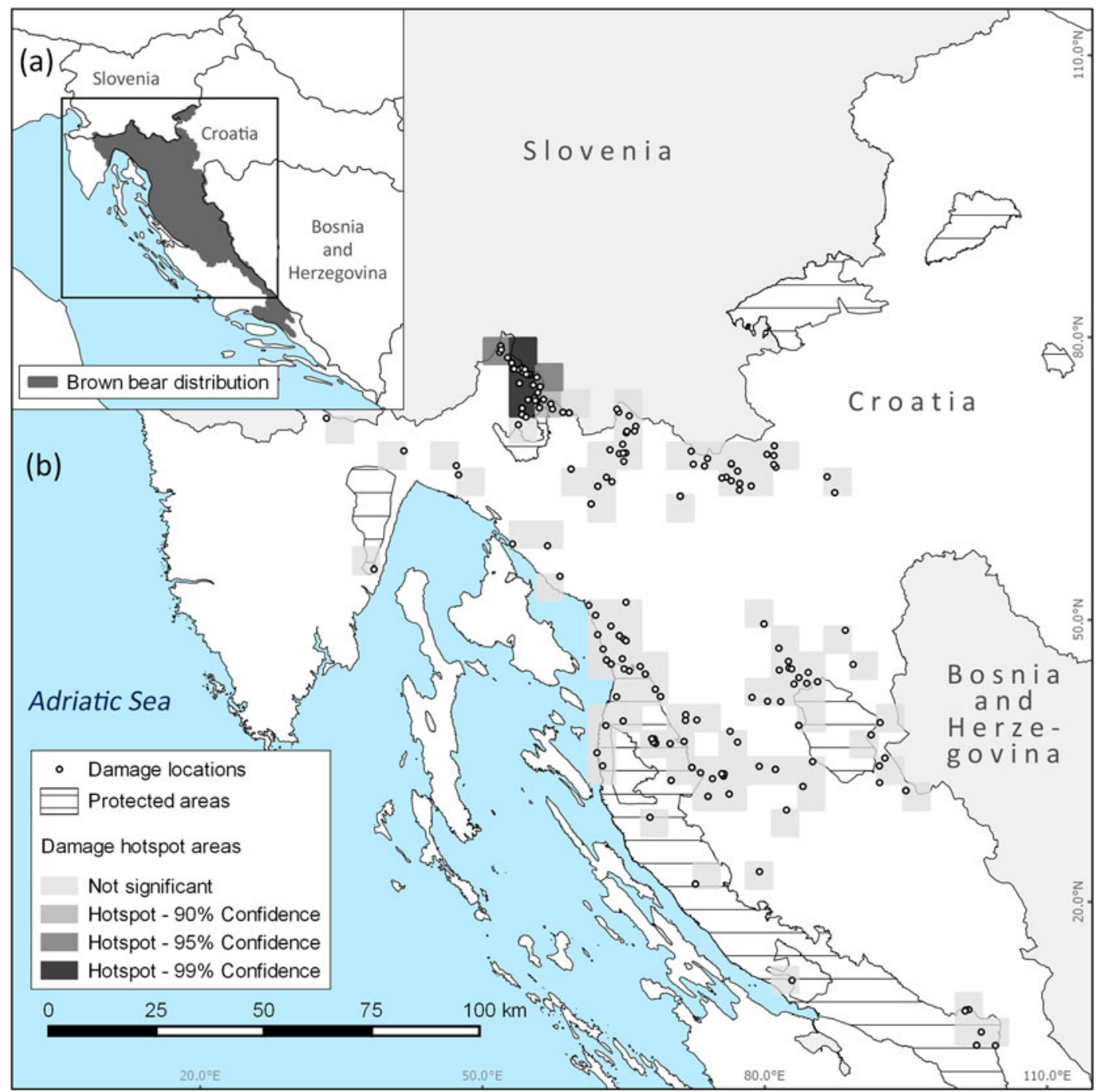

FIG. 2 Brown bear distribution (a) and damage claim locations and hotspots (b) in Croatia for 2004-2014.

landscape protection status and bear population characteristics hypotheses, respectively (Table 2; Supplementary Material 1). The hybrid hypothesis models had lower AICc values (1276.9-1278.9), with a minimum $\triangle \mathrm{AICc}$ of 4.7 for the lowest model for the other hypotheses, and thus had the highest support. Of the models built for this hypothesis, two were the most parsimonious, having $\triangle$ AICc $<2$ (Table 2). However, the $\Delta$ AICc values of the second-best model were close to the threshold of 2: the difference is because the best model has one variable less (see AICc formula in Burnham \& Anderson, 2002). Model averaging is less appropriate in such situations and the most parsimonious model should be selected (Banner \& Higgs, 2017). For the three variables included in the best models of the hybrid hypothesis, the $95 \%$ confidence interval did not include zero, so it is possible to determine whether their effect on the dependent value is positive or negative. Distance to the nearest protected area had a negative effect on the number of bear damage events per $\mathrm{km}^{2}$, whereas the number of villages and the per cent of forest cover within the hunting reserves had a positive effect (Table 3 ). The best model's pseudo $\mathrm{R}^{2}$ was 0.097 (Table 3) and was better fitted than the null model $\left(\chi^{2}=1377.4 ; \mathrm{P}<0.001\right.$; Table 3$)$.

\section{Discussion}

To address human-bear conflicts effectively it is imperative to identify the types of damage and the geographical distribution of damage events. This is critical for effective wildlife management, conservation planning and for targeting conflict mitigation measures in areas where negative impacts on people and bears can be minimized.

The majority $(60 \%)$ of compensation claims related to bears in Croatia were made for damage to crops and orchards. In contrast, Bautista et al. (2017) found that $>50 \%$ of bear damage events in western Europe involved livestock losses and destruction of apiaries. This difference is 
TABLE 2 Best generalized linear regression models $(\Delta \mathrm{AICc}<2)$ for each hypothesis formulated to explain variation in bear damage frequency, ranked by the $\triangle \mathrm{AICc}$ values. Overall best models are in bold.

\begin{tabular}{|c|c|c|c|c|c|}
\hline Model & $\begin{array}{l}\text { Degrees of } \\
\text { freedom }\end{array}$ & $\operatorname{AICc}^{1}$ & $\Delta \mathrm{AICc}^{2}$ & $\begin{array}{l}\text { Overall } \\
\Delta \mathrm{AICc}^{3}\end{array}$ & $\begin{array}{l}\text { Akaike } \\
\text { weight }\end{array}$ \\
\hline \multicolumn{6}{|l|}{ Hypothesis 1: Land cover } \\
\hline No. of villages $+\%$ Forest cover & 4 & 1281.61 & 0.00 & 4.70 & 0.178 \\
\hline$\%$ Forest cover & 3 & 1282.63 & 1.02 & 5.72 & 0.107 \\
\hline No. of villages $+\%$ Forest cover $+\%$ Artificial surfaces $\&$ houses & 5 & 1282.75 & 1.14 & 5.84 & 0.101 \\
\hline$\%$ Forest cover $+\%$ Heterogeneous agricultural areas & 5 & 1283.20 & 1.59 & 6.29 & 0.08 \\
\hline$\%$ Arable land \& permanent crops $+\%$ Forest cover & 5 & 1283.26 & 1.65 & 6.35 & 0.078 \\
\hline \multicolumn{6}{|l|}{ Hypothesis 2: Landscape protection status } \\
\hline Distance to protected areas & 3 & 1284.60 & 0.00 & 7.69 & 1.000 \\
\hline \multicolumn{6}{|l|}{ Hypothesis 3: Bear population characteristics } \\
\hline No. of bears $\geq 8$ years old hunted + Type of bear occurrence & 4 & 1285.24 & 0.00 & 8.33 & 0.400 \\
\hline Type of bear occurrence & 3 & 1285.49 & 0.25 & 8.58 & 0.355 \\
\hline No. of bears $\geq 8$ years old hunted & 3 & 1286.87 & 1.63 & 9.96 & 0.177 \\
\hline \multicolumn{6}{|l|}{ Hypothesis 4: Hybrid } \\
\hline Distance to protected areas + No. of villages $+\%$ Forest cover & 5 & 1276.91 & 0.00 & $0.00^{4}$ & 0.395 \\
\hline $\begin{array}{l}\text { Type of bear occurrence }+ \text { Distance to protected areas }+ \text { No. of } \\
\text { villages }+\% \text { Forest cover }\end{array}$ & 6 & 1278.89 & 1.98 & $1.98^{5}$ & 0.146 \\
\hline
\end{tabular}

${ }^{1}$ Akaike Information Criterion, adjusted for small sample size.

${ }^{2}$ Difference from best ranking (lowest AIC) model for the same hypothesis.

${ }^{3}$ Difference from best ranking (lowest AIC) model across all hypotheses.

${ }^{4}$ Best model.

${ }^{5}$ Second-best model.

TABLE 3 Variables included in overall best model (hybrid hypothesis), and their coefficients (standardized using the partial standard deviations), standard errors, $z$-values, significance and 95\% CI. Variables for which the $95 \%$ CI does not include zero are in bold.

\begin{tabular}{lcccc}
\hline & & \multicolumn{2}{c}{ Significance } \\
Variable & Coefficient \pm SE & $z$-value & $\mathrm{P}(>|z|)$ & $95 \%$ CI \\
\hline Intercept & $-0.399 \pm 1.764$ & -0.226 & 0.821 & $-3.858-3.060$ \\
Distance to protected areas & $-\mathbf{0 . 0 8 0} \pm \mathbf{0 . 0 3 1}$ & $-\mathbf{2 . 6 0 6}$ & $\mathbf{0 . 0 1 0}$ & $\mathbf{- 0 . 1 4 0 - - 0 . 0 2 0}$ \\
No. of villages & $\mathbf{0 . 1 5 8} \pm \mathbf{0 . 0 7 7}$ & $\mathbf{2 . 0 6 4}$ & $\mathbf{0 . 0 4 1}$ & $\mathbf{0 . 0 0 8 - 0 . 3 0 9}$ \\
\% Forest cover & $\mathbf{0 . 0 6 6} \pm \mathbf{0 . 0 2 5}$ & $\mathbf{2 . 6 3 1}$ & $\mathbf{0 . 0 0 9}$ & $\mathbf{0 . 0 1 7 - 0 . 1 1 5}$ \\
\hline
\end{tabular}

probably a result of higher accessibility and availability of crops and orchards to bears in Croatia, although no systematic data are currently available regarding the availability of such commodities in Croatia. Compensation costs were highest for damage to crops, livestock or domestic animals, and beehives, each accounting for c. $21 \%$ of the total compensation payments made (i.e. together, representing $63 \%$ of the total payments). There was a high, positive correlation between the compensation paid and the damage associated with beehives and wildlife feeders, with the converse for orchards. Beehives and feeder structures are highly valuable and damage to them often results in complete economic loss. In orchards, bears may feed in a less destructive manner, picking fruit from trees and causing less damage as a result, although they may occasionally destroy trees (Mahmoud et al., 2017).

There was no trend in the number of damage events per year during 2004-2014, although in 2005 the number of damage claims was particularly high, with 92 recorded events. Local communities reported a sharp decrease in beechnut Fagus sylvatica and wild berry abundance in this year (DH, pers. obs.). This shortage of forest foods may have led bears closer to villages in search of alternative food sources and may have resulted in an increased number of damage events. Although the bear population appears to be increasing in Croatia (Bautista et al., 2017), the mean number of damage claims per year per bear is one of the lowest in Europe (Bautista et al., 2017).

The application of effective preventative measures or an increase in habitat productivity may be contributing to the relatively low and stable number of damage claims. However, further research is needed to examine the mechanisms behind this pattern.

A possible factor could be supplementary feeding during hunting periods (March-May and September-December) in Croatia, which, together with abundant wild forest 
foods, may keep bears away from human settlements because it reduces their need to seek and exploit anthropogenic food sources (Bautista et al., 2017). However, it is the converse in Slovenia (Jerina et al., 2013; Kavčič et al., 2013), with an increase in bear densities and bear-related damage events apparently linked to supplementary feeding. Such differences may be linked to specific landscape characteristics and species distribution patterns, but the exact reasons are difficult to determine. The bear population in Slovenia is concentrated in only $19 \%$ of the country, reaching mean densities of 13 bears/100 $\mathrm{km}^{2}$ and high natality rates in those areas, which are supported by supplementary feeding sites (Jerina et al., 2013; Kavčič et al., 2013). In Croatia the bear population is concentrated in $21 \%$ of the country and the mean density is lower than in Slovenia (8 bears $/ 100 \mathrm{~km}^{2}$ ). The higher bear density in Slovenia results in a higher number of bears inhabiting areas near human settlements, and the spatial distribution of forests and settlements allows bears to visit feeding sites in forests and human settlements during the same night (Kavčič et al., 2013), increasing the likelihood of damage.

Our data confirm that agricultural or livestock areas without protective measures are more likely to be damaged by bears. Most damage to beehives and livestock is avoidable, considering that effective protection measures exist (Swenson et al., 2000). Electric fences, for example, are effective against bears (Coordination Board for Bear Management in Austria, 2005), but many farmers are still reluctant to use them, probably because of the associated cost. Little research has been done in Croatia to test the efficacy and functionality of damage protection measures, but farmers should be involved in developing and implementing preventative measures that could reduce damage claims. Crop protection can be more costly than the protection of livestock and beehives, particularly for large fields, but alternative approaches can be implemented. For example, it is common practice in Croatia for hunting ground managers to compensate the owners of damaged cereal crop fields by providing an amount of replacement cereals equal to the crop loss caused by bears rather than through financial compensation.

Although the number of damage events affecting livestock or domestic animals was lower when protective measures were in place, there is a tendency for a greater number of animals to be killed per attack. This could be because confined domestic animals become more vulnerable when bears destroy or overcome the protective measures, as their ability to escape is limited by the barriers put in place to prevent access.

Although Croatia has intermediate levels of livestock density within the European Union (EU; Eurostat, 2016) and bears do cause damage to livestock or domestic animals, the country's annual per capita loss of livestock to bears (o.05) is the lowest among European countries. For example, in Sweden, which has one of the lowest EU livestock densities (Eurostat, 2016), the annual per capita loss value is twice that in Croatia (Kaczensky, 1999). However, annual per capita loss estimates are dependent on the robustness of bear population estimates. We used the official estimates published by the Croatia government, but these may not be accurate because hunting organizations often deal with compensation claims without reporting them to government institutions; our results should therefore be interpreted cautiously. This situation could be related to the compensation method used in Croatia. Because a majority $(>75 \%)$ of hunters are also farmers, and as a hunting right, land owners are responsible for damage management in Croatia, they may be more protective of their livestock or domestic animals compared to their counterparts elsewhere in Europe, for example by keeping their animals in shelters during the night when bears are more active. Most of the damage associated with livestock is a result of predation on sheep, one of the preferred prey of brown bears in the area, which is consistent with data collected in other European countries (e.g. Slovenia; Kavčič et al., 2013). Farmers in Croatia traditionally manage sheep flocks in open areas, making them easier prey for bears (Fourli, 1999; Dečak et al., 2005; Huber et al., 2008b). Similarly, the high number of chickens killed per attack is a result of the management practice of keeping large numbers of chickens in henhouses.

Beehive annual per capita loss in Croatia (0.03) is lower than in other European countries, e.g. Greece (1.0; Karamanlidis et al., 2011). This may be a result of the higher numbers of beehives available per location in the brown bear range in Greece compared to Croatia and probably explains a higher number of beehives being damaged in an attack when unprotected (Svečnjak et al., 2008).

Preventative measures are an important tool for mitigating brown bear damage, but some stakeholders do not apply them. We recommend that compensation should be linked to the implementation of damage prevention measures (Coordination Board for Bear Management in Austria, 2005) to encourage their use and ensure a low level of damage (and consequently of cost and conflict). Hunter-farmers are more likely to implement preventative measures because they are involved with the institutions that pay for bear damage. The amount of damage and number of claims may decrease when protective measures are implemented, with a consequent amelioration of human-bear conflict.

We detected a damage hotspot in the north of Croatia near Risnjak National Park. This protected area $\left(63.5 \mathrm{~km}^{2}\right)$ is relatively small compared to the size of a typical brown bear home range (224 and $147 \mathrm{~km}^{2}$ for males and females, respectively; Huber \& Roth, 1993). However, the Park is a refuge for wildlife because of its undisturbed habitat and it is probably important for bears because it provides dens where they can hibernate more safely than in agricultural areas (Petram et al., 2004).

The conflict in this area could be a result of the bears' population dynamics in the adjacent protected area. Our 
model results indicated that hunting reserves close to protected areas had a higher damage frequency, and that areas with higher forest cover and a higher concentration of villages were more likely to suffer damage. This may indicate a synergistic effect of forests as a protective environment where bears can move freely without being detected (Posillico et al., 2004), and the presence of human activity, which may provide easily accessible food for bears, resulting in an increased number of damage events (Northrup et al., 2012). Mitigation efforts should therefore be focused on agricultural landscapes near protected areas and forests.

The robustness of our analysis depends on the quality of the data on damage reports, and not all damage claims may be reported to the national authorities. However, given that compensation is paid only if damage is reported, we are confident that the hotspot we identified is based on a real pattern of damage clustering in this area.

Although our analysis has the potential to improve human-wildlife coexistence in Croatia, our results also show that only a small fraction of the data variability is explained by our models. Other factors that were not considered may influence patterns of damage, indicating the need for a broader analysis of the determinants of damage in Croatia. The close relation between those making claims (i.e. farmerhunters) and the organizations responsible for compensation payments presents an opportunity to reduce conflict further through prevention. Such an approach would help maintain economic sustainability and cultural traditions in Croatia while also protecting the brown bear population.

Acknowledgements This study was supported by the LIFE DINALP BEAR project, EURONATUR and Bernd Thies Foundation, and the Ministry of Agriculture of Croatia. DH, LMR and CF were supported financially by the University of Aveiro (Department of Biology), CESAM (UID/AMB/50017), and FCT/ MEC through national funds, and co-funding by the FEDER within the PT2020 Partnership Agreement and Compete 2020.

Author contributions Data collection: DH and SR; data analysis: $\mathrm{DH}, \mathrm{SR}$ and LMR; writing and revisions: $\mathrm{DH}, \mathrm{LMR}, \mathrm{CF}, \mathrm{DH}$ and SMW; project coordination: ĐH.

\section{Conflicts of interest None.}

Ethical standards This research complies with the Oryx Code of Conduct for authors.

\section{References}

Banner, K.M. \& Higgs, M.D. (2017) Considerations for assessing model averaging of regression coefficients. Ecological Applications, 27, 78-93.

B ARton, K. (2015) MuMIn: Multi-Model Inference. R package version 1.13.4. Http://CRAN.R-project.org/package=MuMIn [accessed 1 June 2018].

Bautista, C., Naves, J., Revilla, E., Fernández, N., Albrecht, J., Scharf, A.K. et al. (2017) Patterns and correlates of claims for brown bear damage on a continental scale. Journal of Applied Ecology, 54, 282-292.

Bišćan, A., Budor, I., Domazetović, Z., Fontana Pudić, K., Francetić, I., Gospočić, S. et al. (2016) Action Plan for Brown Bear Management in Republic of Croatia for 2016. Ministry of Agriculture and Ministry of Environmental and Nature Protection. Zagreb, Croatia. [In Croatian]

Bruggers, R.L., Owens, R. \& Hoffman, T. (2002) Wildlife damage management research needs: perceptions of scientists, wildlife managers, and stakeholders of the USDA/Wildlife Services program. International Biodeterioration \& Biodegradation, 49, 213-223.

Burnham, K.P. \& Anderson, D.R. (2002) Model Selection and Multimodel Inference: A Practical Information-theoretic Approach. Springer Verlag, New York, USA.

Can, Ö.E., D’Cruze, N., Garshelis, D.L., Beecham, J. \& Macdonald, D.W. (2014) Resolving human-bear conflict: a global survey of countries, experts, and key factors. Conservation Letters, 7 , 501-513.

Cao, K.-A.L., Rossow, D., Robert-Granié, C. \& Besse, P. (2008) A sparse PLS for variable selection when integrating omics data. Statistical Applications in Genetics and Molecular Biology, 7, 1-29.

Carrascal, L.M., Galván, I. \& Gordo, O. (2009) Partial least squares regression as an alternative to current regression methods used in ecology. Oikos, 118, 681-69o.

CLC (2012) CORINE Land Cover 2012. European Environment Agency, Copenhagen, Denmark. Http://land.copernicus.eu/paneuropean/corine-land-cover/clc-2012/view [accessed 1 June 2018].

Coordination Board for Bear Management in Austria (2005) Bears in Austria - A Management Plan. Reviewed version 2005. WWF Österreich, Wien, Austria.

DeČAK, Đ., Frković, A., Grubešić, M., Huber, Đ., IViČEk, B., Kulić, B. et al. (2005) Brown Bear Management Plan for the Republic of Croatia. Ministry of Agriculture, Forestry and Water Management, Zagreb, Croatia.

Dobson, A.J. (2002) An Introduction to Generalized Linear Models. Chapman \& Hall, Boca Raton, USA.

Eurostat (2016) Agriculture, Forestry and Fishery Statistics - 2016 Edition. Publications Office of the European Union, Luxembourg.

Fourli, M. (1999) Compensation for Damage Caused by Bears and Wolves in the European Union: Experiences from LIFE-Nature Projects. European Commission, Luxembourg City, Luxembourg.

Götz, O., Liehr-Gobbers, K. \& Krafft, M. (2010) Evaluation of structural equation models using the partial least squares (PLS) approach. In Handbook of Partial Least Squares, Springer Handbooks of Computational Statistics (eds V.E. Vinzi, W.W. Chin, J. Henseler \& H. Wang), pp. 691-711. Springer Verlag, Berlin and Heidelberg, Germany.

Gunther, K.A., Haroldson, M.A., Frey, K., Cain, S.L., Copeland, J. \& SChwARTZ, C.C. (2004) Grizzly bear-human conflicts in the Greater Yellowstone ecosystem, 1992-200o. Ursus, 15, 10-22.

Hansen, A.J. (2011) Contribution of source-sink theory to protected area science. In Sources, Sinks, and Sustainability Across Landscapes (eds J. Liu, V. Hull, A. Morzillo \& J. Wiens), pp. 339-36o. Cambridge University Press, Cambridge, UK.

Huber, D. \& Roth, H.U. (1993) Movements of European brown bears in Croatia. Acta Theriologica, 38, 151-159.

Huber, Đ., Kusak, J., Majić-Skrbinšek, A., Majnarić, D. \& SINDIČIĆ, M. (2008a) A multidimensional approach to managing the European brown bear in Croatia. Ursus, 19, 22-32.

Huber, Đ., Jakšić, Z., Frković, A., ŠTahan, Ž., Kusak, J., Majnarić, D. et al. (2008b) Brown Bear Management Plan for the Republic of Croatia. Ministry of Regional Development, Forestry and Water Management, Directorate for Hunting and Ministry of Culture, Directorate for the Protection of Nature, Zagreb, Croatia. 
Jerina, K., Jonozovič, M., Krofel, M. \& Skrbinšek, T. (2013) Range and local population densities of brown bear Ursus arctos in Slovenia. European Journal of Wildlife Research, 59, 459-467.

KaCZENSKY, P. (1999) Large carnivore depredation on livestock in Europe. Ursus, 11, 59-71.

Karamanlidis, A., Sanopoulos, A., Georgiadis, L. \& Zedrosser, A. (2011) Structural and economic aspects of human-bear conflicts in Greece. Ursus, 22, 141-151.

KavČič, I., Adamič, M., Kaczensky, P., Krofel, M. \& Jerina, K. (2013) Supplemental feeding with carrion is not reducing brown bear depredations on sheep in Slovenia. Ursus, 24, 111-119.

Knott, E.J., Bunnefeld, N., Huber, Đ., Reljić, S., Kereži, V. \& Milner-Gulland, E.J. (2014) The potential impacts of changes in bear hunting policy for hunting organisations in Croatia. European Journal of Wildlife Research, 60, 85-97.

Kocijan, I. \& Huber, Đ. (2008) Conservation Genetics of Brown Bears in Croatia. Final Report. Project: Gaining and Maintaining Public Acceptance of Brown bear in Croatia (BBI-Matra/2006/o20 through ALERTIS), Zagreb, Croatia.

Komsta, L. (2011) Outliers: Tests for outliers. R package version o.14. Http://CRAN.R-project.org/package=outliers [accessed 1 June 2018].

KRUUK, H. (2002) Hunter and Hunted. Relationships between Carnivores and People. Cambridge University Press, Cambridge, UK.

Mahmoud, M., Qashqaei, A.T., Marashi, M. \& Nejat, F. (2017) Seasonal human-brown bear conflicts in northern Iran: implications for conservation. Zoology and Ecology, 27, 100-102.

Majić, A., Marino Taussig de Bodonia, A., Huber, Đ. \& Bunnefeld, N. (2011) Dynamics of public attitudes toward bears and the role of bear hunting in Croatia. Biological Conservation, 144, 3018-3027.

Northrup, J.M., Stenhouse, G.B. \& Boyce, M.S. (2012) Agricultural lands as ecological traps for grizzly bears. Animal Conservation, 15, 369-377.

Nyhus, P., Fischer, H., Madden, F. \& Osofsky, S. (2003) Taking the bite out of wildlife damage. Conservation in Practice, 4, 37-43.

Nyhus, P., Osofsky, S., Ferraro, P., Fischer, H. \& Madden, F. (2005) Bearing the costs of human-wildlife conflict: the challenges of compensation schemes. In People and Wildlife: Conflict or Coexistence? (eds R. Woodroffe, S. Thirgood \& A. Rabinowitz), pp. 107-121. Cambridge University Press, Cambridge, UK.

Ord, J.K. \& Getis, A. (1995) Local spatial autocorrelation statistics: distributional issues and an application. Geographical Analysis, 27, 286-306.

Petram, W., Knauer, F. \& Kaczensky, P. (2004) Human influence on the choice of winter dens by European brown bears in Slovenia. Biological Conservation, 119, 129-136.

Posillico, M., Meriggi, A., Pagnin, E., Lovari, S. \& Russo, L. (2004) A habitat model for brown bear conservation and land use planning in the central Apennines. Biological Conservation, 118, 141-150.

R Development Core Team (2015) R: A Language and Environment for Statistical Computing. R Foundation for
Statistical Computing, Vienna, Austria. Http://www.R-project.org [accessed 1 June 2018].

Rigg, R., Findoo, S., Wechselberger, M., Gorman, M.L., Sillero-Zubiri, C. \& Macdonald, D.W. (2011) Mitigating carnivore-livestock conflict in Europe: lessons from Slovakia. Oryx, 45, 272-280.

Roy, P.P. \& Roy, K. (2008) On some aspects of variable selection for partial least squares regression models. QSAR \& Combinatorial Science, 27, 302-313.

SAncheZ, G. (2012) plsdepot: Partial Least Squares (PLS) data analysis methods. R package version o.1.17. Http://CRAN.R-project.org/ package $=$ plsdepot [accessed 1 June 2018].

Schwerdtner, K. \& Gruber, B. (2007) A conceptual framework for damage compensation schemes. Biological Conservation, 134, 354-360.

Servheen, C., Herrero, S. \& Peyton, B. (eds) (1999) Bears: Status Survey and Conservation Action Plan. International Union for the Conservation of Nature and Natural Resources, Gland, Switzerland.

Skrbinšek, T., Bragalanti, N., Calderolla, S., Groff, C., Huber, D., Kaczensky, P. et al. (2015) 2015 Annual Population Status Report for Brown Bears in Northern Dinaric Mountains and Eastern Alps. Life DinAlp bear report (LIFE13 NAT/SI/ooo550), Zagreb, Croatia.

Songchitruksa, P. \& Zeng, X. (2010) Getis-Ord spatial statistics to identify hot spots by using incident management data. Transportation Research Record: Journal of the Transportation Research Board, 2165, 42-51.

Svečnjak, L., Hegić, G., Kezić, J., Turšić, M., Dražić, M.M., Bubalo, D. \& Kezić, N. (2008) The state of beekeeping in Croatia. Central European Journal of Agriculture, 9, 475-482.

Swenson, J.E., Gerstl, N., Dahle, B. \& Zedrosser, A. (200o) Action plan for the conservation of the brown bear (Ursus arctos) in Europe. Nature and Environment Series (Council of Europe, Strasbourg), 114, 1-70.

Treves, A. \& Karanth, U.K. (2003) Human-carnivore conflict and perspectives on carnivore management worldwide. Conservation Biology, 17, 1491-1499.

Troumborst, A. (2010) Managing the carnivore comeback: international and EU species protection law and the return of lynx, wolf and bear to Western Europe. Journal of Environmental Law, 22, 347-372.

Wilson, S.M., Graham, J.A., Mattson, D.J. \& Madel, M.J. (2006) landscape conditions predisposing grizzly bears to conflict on private agricultural lands in the western USA. Biological Conservation, 130, 47-59.

ZAR, J.H. (2010) Biostatistical Analysis. Pearson Prentice Hall, Upper Saddle River, London, UK.

Zedrosser, A., Dahle, B., Swenson, J.E. \& Gerstl, N. (2000) Status and management of the brown bear in Europe. Ursus, 12, 9-20.

Zuur, A.F., Ieno, E.N. \& Smith, G.M. (2007) Analysing Ecological Data. Springer, New York, USA. 